\title{
PENGARUH ADVERSITY QUOTIENT TERHADAP MOTIVASI BELAJAR SISWA PADA MATA PELAJARAN EKONIMO DI SEKOLAH MENENGAH ATAS NEGERI 2 SIAK HULU
}

The Effect Of Adversity Quotient toward Students' Learning Motivation In Economics at the State Senior High School of 2 Siak Hulu

Yulia Novita ${ }^{*)}$ Salmiah**)Ayu Isnaeni Savaroza ${ }^{* * *}$

E-mail: vulia.novita@uin-suska.ac.id

*)**)***) Pendidikan Ekonomi, FTK UIN Suska Riau

\begin{abstract}
This research aims to get information about how big the effect adversity quotient toward Student's Learning Motivation in Economics at the State Senior High School of 2 Siak Hulu. The background of the research were some student cheated in doing their tasks, they did not submit their assignment on time, they did not bring their economics textbooks, and they did not study seriously. This was a quantitative research. The subject of this research was the eleventh grade students whose major were social science. The object of this research was the effect adversity quotient to word students' learning motivation. The number of sample of this research were 127 students. The research used random sampling technique. The data collection technique used was questionnaire and documentations. This technique of analysis used to examine the hypothesis was simple linier regression. Based on the result of the research and data analysis, it was found that $r_{o}$ (observed) 0,688 bigger than $r_{t}$ (table) with the level of significance $5 \%(0,1743)$ and $1 \%(0,2278)$ at $(0,1743<0,688>0,2278)$ or that there is a significant effect of adversity quotient toward students' learning motivation in economics at the State Senior High School of 2 Siak Hulu. The percentage of adversity quotient effect toward students' learning motivation was $47,3 \%$ while the rest $52,7 \%$ was influenced by other variables which were not included in this research.
\end{abstract}

Key words: Adversity Quotient, Student' Learning Motivation 


\section{PENDAHULUAN}

Motivasi belajar sangat diperlukan siswa sebagai subjek yang melakukan proses belajar. Tanpa adanya motivasi seseorang tidak akan bisa melakukan tindakan untuk belajar, karena keinginannya untuk belajar tidak akan muncul tanpa adanya motivasi yang kuat. Seorang yang belajar dengan motivasi yang kuat akan melaksanakan semua kegiatan belajarnya dengan sungguhsungguh, penuh gairah atau semangat. Sebaliknya, belajar dengan motivasi lemah akan malas bahkan tidak mau mengerjakan tugas-tugas yang berhubungan dengan pelajaran ( Dalyono: 2014).

Motivasi belajar merupakan kekuatan (power motivation), daya pendorong (driving force) atau alat pembangun kesedian dan keinginan yang kuat dalam diri siswa untuk belajar secara aktif, kreatif, inovatif dan menyenangkan dalam rangka perubahan perilaku baik dalam aspek kognitif, afektif, dan psikomotorik.(Nanang Hanafiah: 2012).

Berdasarkan pendapat ahli di atas dapat disimpulkan bahwa, motivasi belajar merupakan daya penggerak dari luar maupun didalam diri siswa yang akan mendorongnya untuk melakukan aktivitas belajar secara aktif, kreatif, efektif, inovatif dan menyenangkan guna mencapai tujuan belajar yang diinginkan.

Mata pelajaran ekonomi merupakan bagian dari mata pelajaran di sekolah yang mempelajari tentang sosial dan perhitungan, tidak dapat dipungkiri bahwa akan adanya kesulitan-kesulitan belajar yang menghambat siswa dalam mencapai tujuan belajar. Siswa yang mengalami kesulitan belajar memiliki berbagai macam respon untuk menanggapi kesulitan tersebut. Ada siswa yang putus asa dan berhenti dalam belajar karena tidak mengerti akan materi pelajaran. Ada pula siswa yang memberikan respon yang baik atas kesulitan yang dihadapinya, di mana siswa tersebut menjadikan kesulitan belajar sebagai cambuk untuk memotivasi dirinya agar belajar lebih giat lagi dan dapat menaklukan kesulitan belajar tersebut sehingga ia dapat memahami materi pelajaran.

Kesulitan yang dihadapi siswa dalam kegiatan belajar dapat diatasi dengan kecerdasan atau kemampuan yang ia miliki. Kecerdasan untuk menghadapi kesulitan dan mampu mengubahnya menjadi sebuah tantangan dinamakan dengan istilah adversity quotient (AQ).

Menurut Stoltz mereka yang AQ-nya tinggi dianggap sebagai orang-orang yang paling memiliki motivasi. Semakin tinggi adversity quotient maka semakin tinggi pula motivasi belajar siswa. Siswa yang memiliki AQ yang tinggi akan mengarahkan segala potensi yang dimilikinya untuk terus semakin termotivasi dalam belajar.(Stoltz P.G, Adversity Quotient : 2005)

Menurut Nashori adversity quotient (AQ) merupakan kemampuan seseorang dalam menggunakan kecerdasannya untuk mengarahkan, mengubah cara berfikir dan tindakannya ketika menghadapi hambatan dan kesulitan yang bisa menyengsarakan dirinya.(Nashori:2007)

Berdasarkan pendapat ahli di atas, dapat disimpulkan bahwa adversity quotient merupakan kecerdasan yang mengarahkan atau merubah cara berfikir, tindakan dalam menghadapi berbagai kesulitan yang dihadapi khususnya dalam proses pembelajaran. 
Berdasarkan hasil pengamatan awal yang penulis lakukan di Sekolah Menengah Atas Negeri 2 Siak Hulu terdapat fenomena siswa yang memiliki adversity quotient (AQ), seperti siswa yang mampu menghadapi kesulitan dalam pembelajaran. Kemudian siswa menyakini potensi yang dimilikinya sehingga dapat membantu dalam mencapai tujuan belajar khususnya pada mata pelajaran ekonomi. Selanjutnya, penulis juga menemukan fenomena yang berkaitan dengan motivasi belajar, yaitu: sebagian siswa Masih ada yang mencontek dalam mengerjakan tugas, Masih ada juga siswa yang tidak mengumpulkan tugas tepat waktu dan bahkan tidak membawa buku pelajaran ekonomi pada saat pelajaran berlangsung.

Berdasarkan fenomena di atas, maka penulis tertarik untuk melakukan penelitian dengan judul, "Pengaruh Adversity Quotient Terhadap Motivasi Belajar Siswa Pada Mata Pelajaran Ekonomi di Sekolah Menengah Atas Negeri 2 Siak Hulu"

\section{METODE PENELITIAN}

Jenis penelitian ini adalah penelitian kuantitatif. Metode yang digunakan penulis dalam penelitian ini adalah expost fakto. Metode expost fakto ialah penelitian yang digunakan untuk meneliti peristiwa yang sudah terjadi dan kemudian melihat ke belakang untuk mengetahui faktor-faktor yang menimbulkan kejadian tersebut. Metode expost fakto bertujuan untuk melacak kembali jika dimungkinkan, apa yang menjadi faktor penyebab terjadinya sesuatu.(Riduwan: 2011)

Penelitian ini dilkukan lakukan pada bulanMaret 2019 di Sekolah Menengah Atas
Negeri 2 Siak Hulu yang beralamat di Jalan Kubang Raya No.62 Kubang Jaya, Siak Hulu, Kabupaten Kampar, Riau 28293.

Subjek pada penelitian ini adalah Siswa Kelas XI IPS 1, XI IPS 2, XI IPS 3, XI IPS 4, XI IPS 5 dan XI IPS 6 di Sekolah Menengah Atas Negeri 2 Siak Hulu yang berjumlah 187 orang.maka penarikan sampel dalam penelitian ini menggunakan sampel secara acak (Random Sampling). Di mana cara pemilihan sampel di sini dengan menggunakan undian, nomor yang terjatuh atau diambil (nomor absen siswa) dari undian tersebut maka nomor itulah yang menjadi sampel.berdasarkan rumus Slovin dalam Riduwan dapatlah sampelnya sebanyak 127 dari XI IPS 1 - XI IPS 6. Sedangkan Teknik Pengumpulan data yang digunakan dalam penelitian ini adalah Angket adalah daftar pertanyaan tertulis yang memerlukan tanggapan baik kesesuaian maupun ketidaksesuaian dari sikap testi. Pertanyaan dan pernyataan yang tertulis pada angket berdasarkan indikator yang diturunkan pada setiap variabel tertentu.(Kasmadi dkk: 2016). Angket dalam penelitian ini digunakan untuk mengumpulkan data tentang adversity quotient dan motivasi belajar siswa di Sekolah Menengah Atas Negeri 2 Siak Hulu, Sebelum angket varibel X dan Y disebarkan terlebih dahulu sudah dilakukan Uji Validitas,dan Reabilitas Instrumen.

Dokumentasi dalam penelitian ini digunakan untuk mengambil data biografi Sekolah Menengah Atas Negeri 2 Siak Hulu, seperti profil sekolah, sejarah sekolah, keadaan siswa, data siswa dan segala hal yang berhubungan dengan administrasi 
sekolah yang berupa arsip maupun tabel yang diperoleh dari TU dan juga kurikulum.

Teknik Analisis data yang digunakan dalam penelitian ini menggunakan deskriptif kuantitatif. (Uji Linieritas,Uji Normalitas dan Uji Regresi Linier Sederhana, Uji Hipotesis dan Uji Kontribusi Variabel X dan Variabel Y).

\section{HASIL DAN PEMBAHASAN}

Penyajian data tentang adversity quotient menggunakan teknik angket. Penyajian data berdasarkan angket yang di berikan kepada siswa kelas XI Jurusan IPS di SMA Negeri 2 Siak Hulu berisi 12 pernyataan dengan responden 127 siswa. Berdasarkan rekapitulasi hasil adversity quotient maka diperoleh data sebagai berikut: "Selalu" sebanyak 733, "Sering" sebanyak 781, “Kadang-kadang”sebanyak 10, "Jarang" sebanyak 0 dan "Tidak Pernah" sebanyak 0. Setelah menghitung angka persentasenya, dapat diperoleh hasilnya yaitu 89,49\%. Dengan demikian dapat dikatakan adversity quotient di SMA Negeri 2 Siak Hulu tergolong sangat baik.

Sedangkan data tentang motivasi belajar belajar siswa disajikan menggunakan teknik pengumpulan data angket adapun angket peneliti gunakan yaitu sebanyak 30 penryataan. Dengan jumlah responden sebanyak 127 orang.Berdasarkan rekapitulasi hasil motivasi belajar siswa maka diperoleh data sebagai berikut: "Selalu" sebanyak 2061, "Sering" sebanyak 1731, "Kadang-kadang” sebanyak 18, "Jarang" sebanyak 0 dan "Tidak Pernah" sebanyak 0 . Setelah menghitung angka persentasenya, dapat diperoleh hasilnya yaitu $90,72 \%$.

Dengan demikian dapat dikatakan
Motivasi Belajar Siswa di SMA Negeri2 Siak Hulu tergolong sangat baik.

Berdasarkan analisis data bahwa adversity quotient memiliki pengaruh yang signifikan terhadap motivasi belajar siswa pada mata pelajaran ekonomi di Sekolah Menengah Atas Negeri 2 Siak Hulu yang terbukti dari nilai $\mathrm{r}$ hitung $>\mathrm{r}$ tabel baik pada taraf signifikan 5\% maupun $1 \%$ atau $(0,1743<0,688>0,2278)$ ini berarti $\mathrm{Ha}$ diterima dan $\mathrm{H}_{\mathrm{o}}$ ditolak. Dengan kata lain semakin baik adversity quotient maka motivasi belajar siswa pada mata pelajaran ekonomi akan semakin baik.

Hasil analisisdiperoleh persamaan regresi linier yaitu $\mathrm{Y}=347,871+0,71 \mathrm{X}$. Artinya setiap terjadi penambahan satusatuan pada variabel X (adversity quotient) maka terjadi kenaikan pada variabel $\mathrm{Y}$ (Motivasi Belajar Siswa) sebesar 0,71. Dengan demikian jika koefisien variabel $X$ (adversity quotient) tetap, maka besarnya koefisien variabel Y (motivasi belajar siswa) yaitu 0,71 dan apabila koefisien regresi variabel X dinaikkan 1 satuan,

Berdasarkan analisis data bahwa adversity quotient memiliki pengaruh yang signifikan terhadap motivasi belajar siswa pada mata pelajaran ekonomi di Sekolah Menengah Atas Negeri 2 Siak Hulu yang terbukti dari nilai $\mathrm{r}$ hitung $>\mathrm{r}$ tabel baik pada taraf signifikan 5\% maupun $1 \%$ atau $(0,1743<0,688>0,2278)$ ini berarti $\mathrm{Ha}$ diterima dan $\mathrm{H}_{\mathrm{o}}$ ditolak. Dengan kata lain semakin baik adversity quotient maka motivasi belajar siswa pada mata pelajaran ekonomi akan semakin baik.

Hasil analisis diperoleh persamaan regresi linier yaitu $\mathrm{Y}=347,871+0,71 \mathrm{X}$. Artinya setiap terjadi penambahan satu- 
satuan pada variabel X (adversity quotient) maka terjadi kenaikan pada variabel $\mathrm{Y}$ (Motivasi Belajar Siswa) sebesar 0,71. Dengan demikian jika koefisien variabel $\mathrm{X}$ (adversity quotient) tetap, maka besarnya koefisien variabel Y (motivasi belajar siswa) yaitu 0,71 dan apabila koefisien regresi variabel $\mathrm{X}$ dinaikkan 1 satuan, maka besar koefisien variabel Y akan naik sebesar 0,71.

Dari hasil pengolahan data menggunakan SPSS 21.0, maka koefisien determinasi ( $r$ square) sebesar 0,473, sehingga kontribusi Adversity Quotient terhadap Motivasi Belajar Siswa pada Mata Pelajaran Ekonomi adalah sebesar 0,473 X $100 \%=47,3 \%$. Sedangkan sisanya dipengaruhi atau dijelaskan oleh variabel lain yang tidak dimasukkan dalam penelitian ini. Koefisien determinasi sebesar 47,3\% dikategorikan rendah.

\section{KESIMPULAN}

Berdasarkan hasil penelitian dan analisis data tentang pengaruh adversity quotient terhadap motivasi belajar siswa dapat diambil kesimpulan bahwa adversity quotient memiliki persentase hasil instrument angket sebesar 89,49\% termasuk dalam kategori sangat baik dan motivasi belajar siswa memiliki persentase hasil instrument angket sebesar 90,72\% termasuk dalam kategori sangat baik. Sedangkan uji korelasi menunjukkan ada pengaruh yang signifikan antara adversity quotient terhadap motivasi belajar siswa di SMA Negeri 2 Siak Hulu baik pada taraf signifikan 5\% maupun $1 \% \quad(0,1743<0,688>0,2278)$ yang dikategorikan baik. Kontribusi adversity quotient terhadap motivasi belajar siswa pada mata pelajaran ekonomi di SMA
Negeri 2 Siak Hulu adalah 47,3\%. Sedangkan sisanya 52,7\% (100\%-47,3\%) dipengaruhi oleh variabel lain yang tidak dimasukkan dalam penelitian ini.

\section{DAFTAR PUSTAKA}

Hanafiah, Nanang \& Cucu Suhana. 2012. Konsep Strategi Pembelajaran. Bandung: PT Refika Aditama

Iskandar. 2010. Metode Penelitian Pendidikan dan Sosial (Kualitatif dan Kuantitatif). Jakarta: Gaung Persada Press.

Kasmadi \& Nia Siti Sunariah. 2016. Panduan Modern Penelitian Kuantitatif. Bandung: Alfabeta

M. Dalyono. 2014. Psikologi Pendidikan. Jakarta: Rineka Cipta.

Nashori, Pelatihan Adversity Intellegence untuk Meningkatkan Kebermaknaan Hidup Remaja Panti Asuhan. No. 23, 2007

Riduwan. 2010. Metode dan Teknik Menyusun Proposal Penelitian. Bandung: Alfabeta.

. 2011. Belajar Mudah Penelitian Untuk Guru dan Karyawan dan Peneliti Pemula. Bandung: Alfabeta 2011. Skala Pengukuran VariabelVariabel Penelitian. Bandung: Alfabeta.

Stoltz P.G. 2005. Adversity Quotient; Mengubah Hambatan Menjadi Peluang Alih bahasa T. Hermaya. Jakarta: Grasindo. 